\title{
Interferon Alfa Subtypes and Levels of Type I Interferons in the Liver and Peripheral Mononuclear Cells in Patients With Chronic Hepatitis $\mathrm{C}$ and Controls
}

\author{
Yurdana Castelruiz, Esther larrea, Patricia Boya, María-Pilar Civeira, and Jesús Prieto
}

\begin{abstract}
Viral infections stimulate the transcription of interferon type I, which includes IFN-alfa (IFN- $\alpha$ ) (13 subtypes) and IFN- $\beta$ (a single substance). Hepatitis C virus (HCV) infection is remarkable by its ability to evade host antiviral defenses; however, there is little information as to whether endogenous IFN is activated or not in this disease. Additionally, despite the fact that the various IF $\mathrm{N}-\alpha$ subtypes may differ in biological activity, there are no data concerning the IF $\mathrm{N}-\alpha$ subtypes specifically expressed in normal and diseased liver tissue. Thus, we have analyzed the IFN- $\alpha$ subtypes and the mRNA levels of type I IFNs in samples of normal liver tissue and in liver from patients with chronic hepatitis C. Similar studies were performed in peripheral blood mononuclear cells (PBMC) from patients and controls. After amplification and cloning of IFN $-\alpha$ CDNA, we observed that 98 of the 100 clones from normal liver tissue corresponded to the IF $\mathrm{N}-\alpha 5$ subtype. However, in livers with chronic hepatitis $C$ and in PBMC from controls and patients, a variety of subtypes, in addition to IFN- $\alpha 5$, were detected, suggesting a participation of infiltrating leukocytes in the production of IFN- $\alpha$ in livers with chronic hepatitis C. As compared with controls, patients with chronic hepatitis $C$ showed a significant increase in IF $-\beta$ mRNA in both the liver and PBMC, while IF $N-\alpha$ mRNA was significantly increased in PBMC but markedly reduced in liver tissue. In conclusion, IFN - $\alpha 5$ is the sole IF $N-\alpha$ subtype expressed in normal liver tissue. The hepatic levels of IF $\mathrm{N}-\alpha$ are reduced in chronic hepatitis $\mathrm{C}$, an event that may favor viral persistence. (HEPATOLOGY 1999;29:1900-1904.)
\end{abstract}

Interferon alfa (IFN- $\alpha$ ) and IFN- $\beta$, two members of the type I IFN family, are produced by a great diversity of cells in response to viral infections. ${ }^{1,2}$ Type I IF N s constitute the first line of defense against viruses by displaying direct antiviral effects and also by interacting with the cytokine cascade and

\footnotetext{
Abbreviations: IFN- $\alpha$, interferon alfa; HCV, hepatitis C virus; PCR, polymerase chain reaction; PBMC, peripheral blood mononuclear cells.

From the Department of Medicine and Liver Unit, Clinica Universitaria, University of Navarra, Pamplona, Spain.

Received December 21, 1998; accepted March 29, 1999.

Supported by grants SAF97-0223 from CICYT (Spain), 1852-95 from Gobierno de Navarra (Spain), and also by Fundacion Echebano (Spain).

Address reprint requests to: Prof. J. Prieto, Department of Medicine, Clínica Universitaria, Apartado 4209, 31080, Pamplona, Spain. E-mail: jprieto@unav.es; fax: 34-948296785.

Copyright (c) 1999 by the American Association for the Study of Liver Diseases.

0270-9139/99/2906-0038\$3.00.0
}

the immune system, having regulatory effects on growth and differentiation of $\mathrm{T}$ cells. . $^{3,4}$

While IFN- $\beta$ is a glycoprotein product of a single gene, IF $-\alpha$ is a family of 13 structurally related polypeptides (subtypes), each encoded by a separate gene. ${ }^{5}$ Human IF $\mathrm{N}-\alpha$ genes are expressed constitutively in organs of normal individuals, ${ }^{6,7}$ and show restricted cell-type expression. ${ }^{8}$ It has been shown that the antiviral activity and immunoregulatory properties differ among IF $\mathrm{N}-\alpha$ subtypes. ${ }^{9}$ However, tissue specificity and the biological role of the diverse IF $\mathrm{N}-\alpha$ subtypes remain to be determined. In particular, little is known concerning the IF N- $\alpha$ subtypes expressed in normal and diseased livers.

Viral infections activate transcription of type I IF N genes. ${ }^{10}$ The promoters of IF N $\alpha$ and IFN- $\beta$ genes contain different response elements. ${ }^{11}$ Functional differences between the promoters explain, at least in part, the tissue-specific expression patterns of the two IFN subfamilies. The specificity is achieved by the interaction of virus-induced cell-specific factors with regulatory domains in the promoters of IFN genes. ${ }^{12,13} \mathrm{As}$ in other chronic viral diseases, ${ }^{14}$ the tendency of hepatitis $C$ virus (HCV) infection to evolve to chronicity may depend not only on its ability to escape immunity,15,16 but al so on its capacity to deactivate the endogenous IFN system. In fact, in vitro studies have suggested that HCV may interfere with intracellular signaling of type I IF s s${ }^{17}$; however, there are no data in the literature on the possible effects of this virus on the transcriptional expression of IF $-\alpha$ and $-\beta$ in vivo. A main reason for this is technical problems, because mRNA of type I IFN is not abundant, and techniques based on CDNA amplification have the risk of amplifying genomic DN A along with CDNA as a result of the fact that type I IFN genes lack introns. In this work, we have analyzed the expression of IF $-\alpha$ subtypes in samples of normal liver tissue obtained at laparotomy and in liver biopsies from patients with chronic hepatitis $C$. In addition, we have used a sensitive and specific polymerase chain reaction (PCR)-based technique to determine the levels of mRNA of IFN $-\alpha$ and $-\beta$ in the liver and peripheral blood mononuclear cells (PBMC) in patients with chronic hepatitis $C$ and controls to better understand the interaction of HCV with the endogenous IFN system.

\section{PATIENTS AND METHODS}

Samples of normal liver tissue were obtained from 11 patients ( 8 males and 3 females; age range, 49-70 years) who underwent laparotomy because of early stages of gastrointestinal neoplasms or uncomplicated hydatidic cyst. These subjects had not received anti-inflammatory or cytotoxic therapy previous to operation, and in all cases, histological examination of the surgical biopsy showed normal liver architecture. We also studied liver biopsies from 16 
patients with chronic hepatitis C ( 9 males and 7 females; age range, 24-71 years), of whom 5 had cirrhosis. Genotype 1 b was found in 11 patients. Liver specimens were also taken from another control group ( $n=12$ ) with miscellaneous liver disorders unrelated to HCV (cirrhosis of alcoholic or cryptogenic origin [ $n=6$ ], hepatitis $B$ surface antigen-positive chronic hepatitis [ $n=5]$, and primary biliary cirrhosis stage II ). In this miscellaneous group, liver damage, as estimated by the histological Knodell's index, was similar to that of patients with chronic HCV infection. Written consent was obtained in all cases.

PBM C were collected from 22 healthy controls ( 12 females; age range, 25-66 years) and 23 patients with chronic hepatitis C (14 males; age range, 29-69 years; 4 with cirrhosis; 21 infected with genotype $1 b)$. Liver biopsy for the study of IFN transcripts was available in 8 of these patients.

In all cases, diagnosis of chronic hepatitis $C$ was based on raised serum transaminases for more than 6 months, positivity for anti$\mathrm{HCV}$ antibodies (second-generation enzyme-linked immunosorbent assay; Ortho Diagnostic Systems, Raritan, NJ), presence of HCV RNA by reverse-transcription PCR in serum, and histological evidence of chronic hepatitis. N one of the patients had received IFN treatment at least for 1 year before the study, except 1 case in which liver biopsy was taken 6 months after finishing treatment.

Total RNA was extracted from liver samples, and IFN- $\alpha$ and IFN- $\beta$ mRNA were determined by semiquantitative reversetranscription PCR in a Perkin-Elmer Gene Amp PCR System 2400 (Perkin Elmer, Foster City, CA). Before the reverse transcription, 2 $\mu \mathrm{g}$ of total RNA was treated with $1 \mathrm{U}$ of deoxyribonuclease (DN ase I amplification grade, Gibco-BRL, Gaithersburg, MD) to remove all the contaminating DNA. In all cases, the presence of traces of DNA was excluded by performing control reactions without reverse transcriptase. RNA was reverse-transcribed (60 minutes at $37^{\circ} \mathrm{C}$ ) with $400 \mathrm{U}$ of M-M uLV reverse transcriptase (Gibco-BRL) in $40-\mu \mathrm{L}$ volume of $5 \times$ reverse-transcriptase buffer $(250 \mathrm{mmol} / \mathrm{L}$ Tris- $\mathrm{HCl}$ [pH 8.3], $375 \mathrm{mmol} / \mathrm{L} \mathrm{KCl}, 15 \mathrm{mmol} / \mathrm{L} \mathrm{M} \mathrm{gCl}_{2}$ ), supplemented with $5 \mathrm{mmol} / \mathrm{L}$ dithiothreitol, $0.5 \mathrm{mmol} / \mathrm{L}$ deoxynucleoside triphosphate (Boehringer Mannheim, Mannheim, Germany), $48 \mathrm{U}$ ribonuclease inhibitor (Promega Corporation, M adison, WI), and 400 ng random hexamers (Boehringer Mannheim, Mannheim, Germany). After heating $\left(95^{\circ} \mathrm{C}, 1\right.$ minute) and quick-chilling on ice, an aliquot of 10 $\mu \mathrm{L}(0.5 \mu \mathrm{g})$ of the complementary DNA pool was used for PCR amplification of IFN $-\alpha$ or IFN $-\beta$ in $50 \mu \mathrm{L}$ of $10 \times$ PCR buffer (160 $\mathrm{mmol} / \mathrm{L}\left[\mathrm{NH}_{4}\right]_{2} \mathrm{SO}_{4}, 670 \mathrm{mmol} / \mathrm{L}$ Tris- $\mathrm{HCl}[\mathrm{pH}$ 8.8], 0.1\% Tween20 ), containing upstream and downstream primers (40 ng each for IFN $-\alpha$ and $60 \mathrm{ng}$ each for (FN- $\beta$ ), $1.2 \mathrm{mmol} / \mathrm{L} \mathrm{MgCl}$, and $2 \mathrm{U}$ of Biotaq DNA polymerase (Bioline, London, UK). Blank reactions with no RNA were performed in all experiments. As internal control for each sample, PCR amplification of a fragment of $\beta$-actin CDNA (using a 10- $\mu \mathrm{L}$ aliquot of the CDNA pool) was performed. IFN- $\alpha$ cDNA fragments were amplified by 30 or 33 cycles (PBMC or liver, respectively) $\left(94^{\circ} \mathrm{C}, 60^{\circ} \mathrm{C}\right.$, and $72^{\circ} \mathrm{C}$ for 20,15 , and 30 seconds for each step, respectively), IFN- $\beta$ was amplified by 30 or 35 cycles (PBMC or liver, respectively) $\left(94^{\circ} \mathrm{C}, 58^{\circ} \mathrm{C}\right.$, and $72^{\circ} \mathrm{C}$ for 20,15 , and 30 seconds for each step, respectively), and $\beta$-actin was amplified by 18 or 25 cycles (PBMC or liver, respectively) $\left(94^{\circ} \mathrm{C}, 55^{\circ} \mathrm{C}\right.$, and $72^{\circ} \mathrm{C}$ for 20,15 , and 30 seconds for each step, respectively), a protocol that avoided interference of the plateau effect. We used universal primers designed to amplify all IFN- $\alpha$ subtypes. Oligonucleotides $\left(5^{\prime}-3^{\prime}\right) \mathrm{d}($ TCCATGAGATGATCCAGCAG) and d(ATTTCTGCTCTGACAACCTCCC) were the upstream and downstream primers, respectively, for amplification of a 274-bp fragment from human IFN $-\alpha$ CDNA $^{18}$ that is located between nucleotides 240-514. ${ }^{19}$ Primers were designed to obtain the same amplification efficiency for all IFN - $\alpha$ subtypes. The two primers correspond to the two most conserved regions among all subtypes. The sequence for annealing of the downstream primer is identical for all of them. The annealing sequence of the upstream primer is the same for subtypes $2,4,5,7$, $8,10,16,17$, and 21 , and it differs in only one nucleotide in subtypes 1, 14, and 22 (this change does not occur in the $3^{\prime}$ end of the primer). Also, no other internal regions for annealing of the primers exist in the different subtypes (Oligo 4.05 Primer Analysis Software, National Bioscience Inc., Plymouth, MN). d(TCTAGCACTGGCTGGAATGAG) and d(GTTTCGGAGGTAACCTGTAAG) were the primers used to amplify a 276-bp fragment from human IFN - $\beta$ cDNA that is located between nucleotides $349-625.20 \mathrm{~d}$ (TCTACAATGAGCTGCGTGTG) and d(GGTGAGGATCTTCATGAGGT) were the primers used for amplification of a 314-bp fragment (nucleotides 1319-2079) from the reported human $\beta$-actin gene sequence. ${ }^{21}$

Identification of IFN - $\alpha$ subtype transcripts was performed by cloning the PCR products using the TOPO TA cloning kit (Invitrogen, $C$ arlsbad, CA). Clones from each insert were sequenced in $A B I$ PRISM 310 Genetic Analyzer (Perkin Elmer) using the dye Rhodamine terminator cycle sequencing kit (Perkin Elmer).

After PCR amplification, $20-\mu \mathrm{L}$ aliquots of the PCR reactions were electrophoresed in $2 \%$ agarose gel stained with ethidium bromide. The bands were visualized with an ultraviolet lamp and analyzed with commercial software (M olecular Analyst/PC, Bio-Rad, Hercules, CA). Finally, values corresponding to IFN- $\alpha$ or IFN- $\beta$ mRNA were normalized to those of $\beta$-actin mRNA, and results were expressed as the ratio of IFN- $\alpha$ or IFN $-\beta$ to $\beta$-actin. When IFN- $\alpha$ and IFN- $\beta$ mRNA values were normalized to those of $\beta$-actin mRNA, it was assumed that $\beta$-actin mRNA was constantly expressed in patients with chronic hepatitis $C$, normal controls, and patients with other liver diseases unrelated to HCV, both in PBMC and liver. In fact, we compared $\beta$-actin mRNA values among the three groups studied, and no differences were observed (data not shown). Constant expression of $\beta$-actin mRNA was also found in a previously reported series of patients and controls in which the same semiquantitative $\mathrm{PCR}$ procedure was used to analyze tumor necrosis factor $\alpha$ mRNA values in liver and PBMC. ${ }^{22}$

Validation experiments on PCR assays using known quantities of total RNA showed linearity of the counts of amplification bands from 0.125 to $1 \mu \mathrm{g}$ in both liver and PBMC for IFN $-\alpha$, IFN $-\beta$, and $\beta$-actin. Thus $0.5 \mu \mathrm{g}$ was chosen as the suitable amount of total RNA to avoid the plateau effect. To analyze whether changes in IFN $-\alpha$ or IFN- $\beta$ mRNA levels resulted in changes in the ratio of IFN- $\alpha$ or IFN- $\beta$ PCR product/ $\beta$-actin PCR product, we performed reversetranscription PCR with $0.1 \mu \mathrm{g}$ of total normal liver RN A containing serial dilutions of known quantities of IFN- $\alpha$ or IFN $-\beta$ riboprobes, which were obtained by run-off transcription of a plasmid that contained a 274- and 276-bp inserts from the human IFN - $\alpha$ and $-\beta$ CDNA. With increasing amounts of IFN $-\alpha$ and $-\beta$ riboprobe used in the reaction, we obtained a progressive increase in the IFN- $\alpha$ or $-\beta / \beta$-actin ratio (data not shown). The coefficient of interassay variation for IFN- $\alpha / \beta$-actin and IFN- $\beta / \beta$-actin was $15 \%$ and $12 \%$, respectively. The identity of the PCR product from IFN $-\alpha$ and IFN $-\beta$ cDNA amplification was verified by automatic sequencing ( $A B \mid$ PRISM 310 Genetic Analyzer, Perkin Elmer)

Detection, quantitation, and genotyping of HCV RNA was performed as previously described.22,23

Results of IFN $-\alpha$ and IFN $-\beta$ are given as mean \pm SEM. N ormality was assessed with the Shapiro-Wilks test. Statistical analysis of IFN- $\alpha$ and IFN- $\beta$ levels in PBM C and in the liver were performed using nonparametric (Kruskal-Wallis and Mann-Whitney U) tests. Associations between quantitative variables were studied with Spearman's correlation coefficient. Qualitative variables were analyzed with the Fisher exact test. All P values were two-tailed. SPSS 6.0 for Windows was used for the statistical analysis.

\section{RESULTS}

IFN- $\alpha$ Subtypes in the Liver and in PBMC. RNA was extracted from liver samples and PBMC, and IFN- $\alpha$ CDNA was amplified with universal primers for all IFN- $\alpha$ subtypes. After cloning and sequencing of PCR products, we found that 98 of the 100 clones derived from six samples of normal liver tissue showed the sequence corresponding to IFN- $\alpha 5$ subtype (Table 1). We also sequenced 98 clones obtained from liver 
TABLE 1. IFN- $\alpha$ Subtypes in Normal Liver Tissue and in Liver From Patients With Chronic Hepatitis C

\begin{tabular}{lcccccccc}
\hline & No. of Clones Tested & $\alpha \mathbf{1}$ & $\alpha \mathbf{4}$ & $\alpha \mathbf{5}$ & $\alpha \mathbf{1 0}$ & $\alpha \mathbf{1 7}$ & $\alpha \mathbf{2 1}$ & $\alpha \mathbf{2 2}$ \\
\hline $\begin{array}{l}\text { Normal Liver } \\
\quad \text { Total } \\
\begin{array}{l}\text { Patients } \\
\text { P 1 }\end{array}\end{array}$ & 100 & 0 & 0 & 98 & 1 & 0 & 0 & 1 \\
P 2 & 16 & 0 & 0 & 12 & 0 & 2 & 2 & 0 \\
P 3 & 15 & 0 & 1 & 10 & 0 & 0 & 4 & 0 \\
P 4 & 20 & 0 & 0 & 20 & 0 & 0 & 0 & 0 \\
P 5 & 5 & 0 & 0 & 5 & 0 & 0 & 0 & 0 \\
P 6 & 16 & 2 & 1 & 10 & 0 & 0 & 3 & 0 \\
P 7 & 14 & 0 & 1 & 12 & 0 & 0 & 1 & 0 \\
Total & 12 & 0 & 0 & 12 & 0 & 0 & 0 & 0 \\
\hline
\end{tabular}

NOTE. Normal liver are samples from 6 normal liver tissues obtained at laparotomy. P 1-7 are samples from 7 different patients with chronic hepatitis $C$. Figures represent the number of CDNA clones showing the sequence corresponding to the indicated IF $\mathrm{N}-\alpha$ subtype.

biopsies from 7 patients with chronic hepatitis C. Of these, only 81 corresponded to IFN $-\alpha 5(P<.001$ as compared with samples of normal liver tissue). In the liver of patients with chronic hepatitis $C$, other subtypes $(\alpha 1, \alpha 4, \alpha 17$, and $\alpha 21)$, in addition to $\alpha 5$, were represented (Table 1), probably reflecting the production of IF $-\alpha$ not only by hepatocytes, but also by infiltrating leukocytes.

As shown in Table 2, a combination of different IFN - $\alpha$ subtypes was found in PBMC from patients with HCV infection and healthy controls. In PBMC from healthy subjects, 15 of 43 clones analyzed corresponded to IF $\mathrm{N}-\alpha 5$, whereas this subtype was found in 31 of 45 clones from PBM $C$ of patients with chronic hepatitis $C(P<.005)$.

Transcriptional Expression of IFN- $\alpha$ and $-\beta$ in the Liver and in PBMC. IFN $-\alpha$ and IFN- $\beta$ mRNA levels were measured in PBM $C$ and liver tissue from patients with chronic hepatitis $C$ and controls (Table 3). The levels of IFN- $\alpha$ mRNA were significantly increased in PBMC from chronic hepatitis $C$ patients as compared with normal controls. However, IFN $-\alpha$ mRNA values were found to be significantly reduced in the liver of patients with chronic hepatitis $C$ with respect to samples of normal liver tissue and also with respect to values found in a miscellaneous group of chronic liver diseases. The five cases with chronic hepatitis $B$ included in the disease control group had values of IFN - $\alpha$ mRNA in the liver $(0.33 \pm$ $0.15)$ similar to those found in normal hepatic tissue and

TABLE 2. IFN- $\alpha$ Subtypes in PBMC From Healthy Controls and From Patients With Chronic Hepatitis C

\begin{tabular}{lccccccccccc}
\hline & No. of Clones Tested & $\alpha \mathbf{1}$ & $\alpha \mathbf{2}$ & $\alpha \mathbf{4}$ & $\alpha \mathbf{5}$ & $\alpha \mathbf{7}$ & $\alpha \mathbf{8}$ & $\alpha \mathbf{1 0}$ & $\alpha \mathbf{1 6}$ & $\alpha \mathbf{2 1}$ & $\alpha \mathbf{2 2}$ \\
\hline $\begin{array}{l}\text { Controls } \\
\quad \text { Total }\end{array}$ & 43 & 14 & 1 & 1 & 15 & 1 & 2 & 2 & 0 & 6 & 1 \\
$\begin{array}{l}\text { Patients } \\
\text { P 1 }\end{array}$ & 8 & 0 & 0 & 0 & 7 & 0 & 0 & 0 & 0 & 1 & 0 \\
P 2 & 9 & 0 & 0 & 0 & 5 & 0 & 0 & 0 & 0 & 4 & 0 \\
P 3 & 11 & 0 & 0 & 2 & 4 & 1 & 0 & 1 & 2 & 0 & 1 \\
P 4 & 8 & 0 & 0 & 0 & 7 & 0 & 0 & 0 & 0 & 1 & 0 \\
P 8 & 9 & 0 & 1 & 0 & 8 & 0 & 0 & 0 & 0 & 0 & 0 \\
Total & 45 & 0 & 1 & 2 & 31 & 1 & 0 & 1 & 2 & 6 & 1 \\
\hline
\end{tabular}

NOTE. Controls are PBMC samples from 5 healthy subjects; P1-8 are PBMC samples from 5 different patients with chronic hepatitis $C$. Figures represent the number of CDNA clones showing the sequence corresponding to the indicated IF $\mathrm{N}-\alpha$ subtype.
TABLE 3. mRNA Levels of Type I IFNs in the Liver and in PBMC From Patients With Chronic Hepatitis C and From Controls

\begin{tabular}{|c|c|c|c|c|c|}
\hline & \multicolumn{3}{|c|}{ Liver } & \multicolumn{2}{|c|}{ PBMC } \\
\hline & $\begin{array}{c}\text { Normal } \\
\text { Liver Tissue } \\
(n=11)\end{array}$ & $\begin{array}{c}\text { Chronic } \\
\text { Hepatitis C } \\
(n=16)\end{array}$ & $\begin{array}{l}\text { Other Liver } \\
\text { Diseases } \\
(n=12)\end{array}$ & $\begin{array}{l}\text { Healthy } \\
\text { Controls } \\
(n=22)\end{array}$ & $\begin{array}{c}\text { Chronic } \\
\text { Hepatitis C } \\
(n=23)\end{array}$ \\
\hline IFN- $\alpha$ & $0.43 \pm 0.12$ & $0.12 \pm 0$ & $0.24 \pm 0.03$ & $0.88 \pm 0.17$ & $0.37 \dagger$ \\
\hline IFN- $\beta$ & $1.03 \pm 0.16$ & $1.73 \pm 0.23 \ddagger$ & $0.92 \pm 0.17$ & $0.76 \pm 0.09$ & $1.41 \pm$ \\
\hline \multicolumn{6}{|c|}{$\begin{array}{l}\text { NOTE. Values are expressed as the ratio IFN }-\alpha \text { or IFN }-\beta \text { mRNA/ } \beta \text {-actin } \\
\text { RNA. Data are given as means } \pm \text { SEM. } \\
* P<.01 \text { vs. normal liver and other liver diseases. } \\
\dagger P<.001 \text { vs. healthy controls. } \\
\ddagger P<.05 \text { vs. normal liver and other liver diseases. }\end{array}$} \\
\hline
\end{tabular}

significantly higher than patients with chronic hepatitis C $(\mathrm{P}<.02)$.

As was the case for IF $N$ - $\alpha$, the levels of IF $-\beta$ mRNA were raised in PBMC from patients with chronic hepatitis $C$ as compared with healthy subjects (Table 3 ). However, in contrast to IFN $-\alpha$, IFN $-\beta$ mRNA was significantly increased in the liver of patients with chronic HCV infection as compared with those found in specimens of normal liver tissue and also as compared with those observed in biopsies from patients with miscellaneous liver disorders (Table 3 ). IFN- $\beta$ mRNA was not increased in hepatic tissue from the 5 patients with chronic hepatitis $B$ included in the disease control group (1.02 \pm 0.74$)$ as compared with values found in normal liver tissue.

Figure 1 shows an example of the amplification bands of IFN- $\alpha$, IFN- $\beta$, and $\beta$-actin CDNAs obtained from specimens of normal liver tissue and liver biopsies from patients with chronic hepatitis C. In each case, the same RN A preparation was used for reverse transcription and amplification of the three gene products. It can be clearly seen that while the intensity of the $\beta$-actin band is similar in all cases, the band corresponding to IFN $-\alpha$ is decreased, while that of IFN $-\beta$ is increased in livers with chronic HCV infection as compared with samples of normal liver tissue.

We found that in patients with chronic hepatitis C, IFN- $\beta$

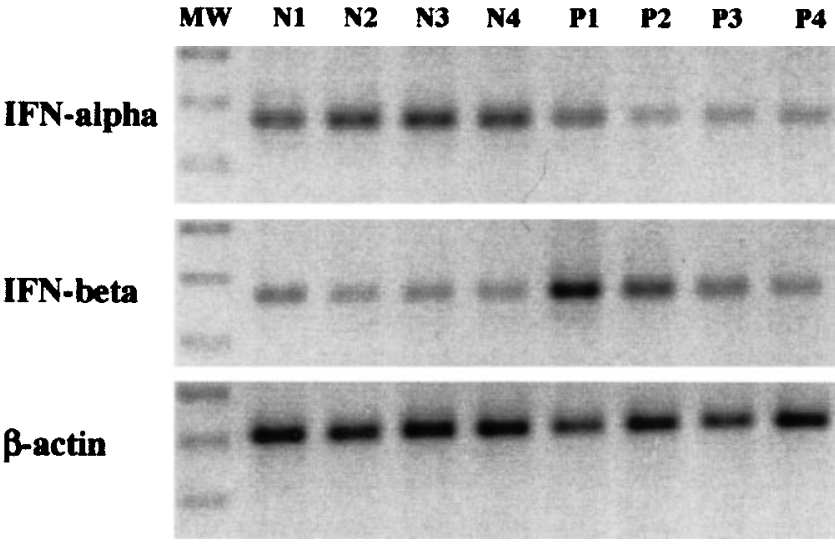

FIG. 1. Amplification bands of IFN- $\alpha, I F N-\beta$, and $\beta$-actin CDNAs obtained from specimens of normal liver tissue $\left(\mathrm{N}_{1}-\mathrm{N}_{4}\right)$ and liver biopsies from patients with chronic hepatitis $C\left(P_{1}-P_{4}\right)$. It can be seen that the band corresponding to IF $\mathrm{N}-\alpha$ is decreased and that of IFN- $\beta$ is increased in livers with chronic HCV infection as compared with samples of normal liver tissue; in contrast, the intensity of the $\beta$-actin band is similar in all cases. MW, molecular weight. 
mRNA values correlated directly with the histological Knodell's index of liver damage $(r=.66 ; P<.01)$ and with serum aspartate aminotransferase $(r=.64 ; \mathrm{P}<.01)$. Although the transcriptional expression of IF $\mathrm{N}-\alpha$ in the liver was substantially reduced in chronic hepatitis $\mathrm{C}$, a significant correlation between hepatic IFN - $\alpha$ mRNA levels and the Knodell's index $(r=.54 ; P<.05)$ was also encountered, suggesting a participation of the mononuclear infiltrate in the production of IFN transcripts. We found no correlation between IF $\mathrm{N}-\alpha$ or IFN - $\beta$ mRN A values (in the liver or in PBMC) and the titer of HCV RNA in serum.

\section{DISCUSSION}

In response to viral infections, IF $\mathrm{N}$ - $\alpha$ is produced by a great diversity of cell types including mononuclear cells, polymorphonuclear leukocytes, hepatocytes, fibroblasts, Kupffer cells, and dendritic cells. ${ }^{24-28}$ IFN- $\beta$ is synthesized mainly by fibroblasts, epithelial cells, and mononuclear cells. ${ }^{29,30}$ On the other hand, different studies have shown that IFN- $\alpha$ is constitutively expressed in a variety of tissues such as liver, spleen, kidney, pancreas, and PBMC.6,7,24 These findings chal lenge the idea that IFNs are produced only in response to viral infection and point to an as-yet-unclear biological function of IFNs in normal tissues. The present study shows that normal liver tissue expresses almost exclusively the IFN- $\alpha 5$ subtype. In contrast with this restriction to only one IFN- $\alpha$ subtype, other subtypes, similar to those found in PBMC, were observed in livers from patients with chronic hepatitis C, possibly reflecting the participation of infiltrating mononuclear cells in the production of IFN- $\alpha$ transcripts. Interestingly, in patients with chronic HCV infection, the pattern of IFN- $\alpha$ subtypes in PBMC was different to that of normal individuals with a preponderance of subtype 5, a finding of unknown biological significance.

The restriction of IFN $-\alpha$ expression in the liver to only IFN- $\alpha 5$ raises questions about the specific physiological activities of this subtype. In fact, it has been shown that, although IFN- $\beta$ and all subtypes of IFN- $\alpha$ bind to the same receptor, differences in intracellular signaling and biological effects exist among them in specific cell types. ${ }^{9,31}$ It is therefore conceivable that IFN - $\alpha 5$ might exert antiviral and other biological effects on liver cells, which could differ from those elicited by other IFN - $\alpha$ subtypes.

$\mathrm{HCV}$ infection is characterized by a pronounced tendency to become chronic. This virus has developed the ability to evade both the IFN system and the immune response through mechanisms that remain unclear. In this study, we show that patients with chronic HCV infection exhibit an enhanced expression of IFN $-\beta$ in both the liver and PBM C, as expected for a virus that can infect both hepatocytes and mononuclear cells. ${ }^{32}$ However, the effects of HCV on IF N- $\alpha$ are different. In patients with chronic hepatitis C, IFN- $\alpha$ mRNA levels are increased in PBMC but markedly reduced in the liver. Thus, $\mathrm{HCV}$ infection causes opposite changes of IF $-\alpha$ and IF $-\beta$ in hepatic tissue, decreasing the expression of the former, while increasing the latter. This finding might be explained by the fact that IFN- $\alpha$ and IFN- $\beta$ are induced in viral infections by different mechanisms, ${ }^{11}$ and it is possible that $\mathrm{HCV}$ may interfere specifically with the induction of IFN $-\alpha$. The selective interference of $\mathrm{HCV}$ with IFN- $\alpha$ expression might indicate a relevant role of IFN- $\alpha$ in controlling this viral infection. Because increased production of IFN- $\alpha$ by hepatocytes has been shown to be associated with resolution of acute viral hepatitis, ${ }^{25}$ one of the strategies by which $\mathrm{HCV}$ succeeds in establishing persistent infection might be through mechanisms that impair the expression of IF $\mathrm{N}-\alpha$ in the liver. The characterization of the HCV gene products possessing the ability to block the transcriptional machinery of IFN- $\alpha$ will undoubtedly help to understand the pathophysiology of this infection and its tendency to chronicity.

An additional observation in this article is the fact that $\mathrm{HCV}$ infection is associated with increased values of IF N- $\alpha$ mRNA in PBMC, while the levels of this transcript are reduced in liver parenchyma. To explain this finding, it should be remembered that IFN- $\alpha$ genes have a regulatory domain within the virus-response element that determines cell-specific gene expression. ${ }^{8}$ Thus, it can be thought that interaction of $\mathrm{HCV}$ with different cell transcription factors in PBM C and in the liver can arbitrate the opposite changes in IFN $-\alpha$ gene expression found in these two tissues in chronic HCV infection.

In patients with chronic hepatitis $C$, we observed a positive correlation between the Knodell index of histological hepatic damage and the level of expression of type I IF Ns in the liver. This observation might be explained by the participation of infiltrating mononuclear cells in the production of IFN $-\alpha$ and - $\beta$. Indeed, studies using monoclonal antibodies have shown the presence of IFN-positive cells in the mononuclear infiltrate of liver biopsies from patients with chronic hepatitis $\mathrm{B}^{26}$ and $\mathrm{C}^{27}$ These investigations have demonstrated a good correlation between the number of IF N-positive cells and the intensity of the histological liver damage.

Finally, considering that IFN- $\alpha 5$ is the subtype mainly expressed in hepatic tissue and that IF $\mathrm{N}-\alpha$ is decreased in the liver of patients with chronic HCV infection, it is tempting to speculate that IF $\mathrm{N}-\alpha 5$ might have a role in the treatment of chronic hepatitis $\mathrm{C}$. This suggestion is supported by studies showing that IFN- $\alpha 5$ is endowed with potent antiviral and antiproliferative properties. ${ }^{9}$ At present, lymphoblastoid IFN (a mixture of subtypes with only a small proportion of IF $-\alpha 5$ ) and the two recombinant IF N s, IF N- $\alpha 2$ a and IFN$\alpha 2 b$, are used to treat chronic hepatitis C, but fewer than 30\% of treated patients exhibit sustained biochemical and virological response. ${ }^{33}$ Thus, more efficient therapies are urgently needed. Our data may stimulate further work on the mechanisms used by HCV to impair transcriptional activation of IFN- $\alpha$ in the liver and on the effects of IFN- $\alpha 5$, the liver-specific IF $-\alpha$ subtype, on HCV replication.

Acknowledgment: The authors thank B. Carte and E. Saez for technical assistance, F. Pardo for provision of normal liver samples, and C. Berasain for advice and comments. Y. Castelruiz and E. Larrea contributed equally to this article.

\section{REFERENCES}

1. Sen G, Lengyel P. The interferon system. J Biol Chem 1992;267:50175020

2. Samuel CE. Antiviral actions of interferon. Interferon-regulated cellular proteins and their surprisingly selective antiviral activities. Virology 1991;183:1-11.

3. Tilg H. New Insights into the mechanisms of interferon alfa: an immunoregulatory and anti-inflammatory cytokine. Gastroenterology 1997;112:1017-1021.

4. Malefyt RW. The role of type I interferons in the differentiation and function of Th1 and Th2 cells. Semin Oncol 1997;24:S94-S98.

5. Diaz MO, Bohlander S, Allen G. Nomenclature of the human interferon genes. J Interferon Cytokine Res 1996;16:179-180.

6. Tovey MG, Streuli M, Gresser I, Gugenheim J, Blanchard B, Guymarho J, 
Vignaux $F$, et al. Interferon messenger RNA is produced constitutively in the organs of normal individuals. Proc N atl Acad Sci U SA 1987;84:50385042.

7. Huang X, Yuan J, Goddard A, Foulis A, James RFL, Lernmark A, Pujol-Borreel R, et al. Interferon expression in the pancreases of patients with type I diabetes. Diabetes 1995;44:658-664.

8. Bisat F, Raj NB, Pitha PM. Differential and cell type specific expression of murine alpha interferon genes is regulated on the transcriptional level. Nucleic Acids Res 1988;16:6067-6083.

9. Foster GR, Rodrigues O, Ghouze F, Schulte-Frohlinde E, Testa D, Liao MJ, Stark GR, et al. Different relative activities of human cell-derived interferon- $\alpha$ subtypes: IFN- $\alpha 8$ has very high antiviral potency. J Interferon Cytokine Res 1996;16:1027-1033.

10. Tanaka N, Taniguchi T. Cytokine gene regulation: regulatory ciselements and DNA binding factors involved in the interferon system. Adv Immunol 1992;52:263-281.

11. MacDonald NJ, Kuhl D, Maguire D, N äf D, Gallant P, Goswamy A, Hug $\mathrm{H}$, et al. Different pathways mediate virus inducibility of the human IFN-al and IFN-b genes. Cell 1990;60:767-779.

12. Au WC, Su Y, Raj NBK, Pitha PM. Virus-mediated induction of interferon- $\alpha$ gene requires cooperation between multiple binding factors in the interferon- $\alpha$ promoter region. J Biol Chem 1993;268:2403224040.

13. Dent $\mathrm{CL}$, Gewert DR. A regulatory domain within virus-response element of the interferon- $\alpha 1$ gene acts as a transcriptional repressor sequence and determinant of cell-specific gene expression. Eur J Biochem 1996;236:895-903.

14. Foster GR, Ackrill AM, Goldin RD, Kerr IM, Thomas HC, Stark GR. Expression of the terminal protein region of hepatitis $B$ virus inhibits cellular responses to interferons $\alpha$ and $\gamma$ double-stranded RNA. Proc Natl Acad Sci U SA 1991;88:2888-2892.

15. Bukh J, Miller RH, Purcell RH. Genetic heterogeneity of hepatitis C virus: quasispecies and genotypes. Semin Liver Dis 1995;15:41-63.

16. Woitas RP, Lechmann M, Jung G, Kaiser R, Sauerbruch T, Spengler U. CD30 induction and cytokine profiles in hepatitis $C$ virus core-specific peripheral blood T Iymphocytes. J Immunol 1997;159:1012-1018.

17. Gale MJ, Korth MJ, Tang N M, Tan SL, Hopkins DA, Dever TE, Polyak SJ, et al. Evidence that hepatitis $C$ virus resistance to interferon is mediated through repression of the PKR protein kinase by the nonstructural $5 \mathrm{~A}$ protein. Virology 1997;230:217-227.

18. Weissmann $\mathrm{C}$, Weber $\mathrm{H}$. The interferon genes. Prog Nucleic Acid Res Mol Biol 1986:33:251-300.

19. Goeddel DV, Leung DW, Dull TJ, Gross M, Lawn RM, McCandliss R, Seeburg $\mathrm{PH}$, et al. The structure of eight distinct cloned human leukocyte interferon cDNAs. Nature 1981;290:20-26.

20. Derynck R, Content J, DeClercq E, Volckaert G, Tavernier J, Devos R,
Fiers W. Isolation and structure of a human fibroblast interferon gene. Nature 1980;285:542-547.

21. Ng SY, Gunning P, Eddy R, Ponte P, Leavitt J, Shows T, Kedes L. Evolution of the functional human $\beta$-actin gene and its multipseudogene family: conservation of noncoding regions and chromosomal dispersion of pseudogenes. Mol Cell Biol 1985;5:2720-2732.

22. Larrea E, García N, Qian C, Civeira MP, Prieto J. Tumor necrosis factor $\alpha$ gene expression and the response to interferon in chronic hepatitis $C$. Hepatology 1996;23:210-217.

23. Gavier B, Martínez-González MA, Riezu-Boj JI, Lasarte JJ, García N, Civeira MP, Prieto J. Viremia after one month of interferon therapy predicts treatment outcome in patients with chronic hepatitis C. Gastroenterology 1998;113:1647-1653.

24. Brandt ER, Linnane AW, Devenish RJ. Expression of IFN A genes in subpopulations of peripheral blood cells. Br J Haematol 1994;86:717725.

25. Nouri-Aria KT, Arnold J, Davison F, Portmann BC, Meager A, Morris AG, Alexander GJ, et al. Hepatic interferon-alpha gene transcripts and products in liver specimens from acute and chronic hepatitis B virus infection. Hepatology 1991;13:1029-1034.

26. Dienes HP, Hess G, Woorsdorfer M, Rossol S, Gallati H, Ramadori G, Meyer-zum-Buschenfelde $\mathrm{KH}$. Ultrastructural localization of interferonproducing cells in the livers of patients with chronic hepatitis $B$. HePATOLOGY 1991;13:321-326.

27. Greenway AL, Hertzog PJ, Devenish RJ, Dudley FJ, McMullen GL, Linnane AW. Immunolocalisation of interferon-alpha in hepatitis $C$ patients and its correlation with response to interferon-alpha therapy. J Hepatol 1994;21:842-852.

28. Ghanekar S, Zheng L, Logar A, N avratil J, Borowski L, Gupta P, Rinaldo C. Cytokine expression by human peripheral blood dendritic cells stimulated in vitro with HIV-1 and herpes simplex virus. J Immunol 1996;157:4028-4036.

29. Pestka S, Baron S. Definition and classsification of the interferons. Methods Enzymol 1981;78:3-14.

30. Reis LFL, Harada H, Wolchok JD, Taniguchi T, Vilcek J. Critical role of a common transcription factor, IRF- 1 , in the regulation of IFN- $\beta$ and IFN-inducible genes. EM BO J 1992;11:185-193.

31. Domanski P, Nadeau OW, Platanias LC, Fish E, Kellum M, Pitha P, Colamonici OR. Differential use of the $\beta_{\mathrm{L}}$ subunit of the typel interferon (IFN) receptor determines signaling specificity for IFN $\alpha 2$ and IFN $\beta$. J Biol Chem 1998;273:3144-3147.

32. Gil B, Qian C, Riezu-Boj JI, Civeira MP, Prieto J. Hepatic and extrahepatic HCV RNA strands in chronic hepatitis C: different patterns of response to interferon treatment. HEPATOLOGY 1993;18:1050-1054.

33. Davis GL. Interferon treatment of chronic hepatitis C. Am J Med 1994;96:41-46. 